\title{
What do we know about sleep paralysis?
}

\author{
Co wiemy o paraliżu sennym?
}

Paulina Wróbel - Knybel ${ }^{1}$ ABDEF, https://orcid.org/0000-0002-4741-5911

Michał Flis ${ }^{2}$ BDEF, https://orcid.org/0000-0002-4831-9091

Rafał Dubiel ${ }^{3} \mathrm{BD}$, https://orcid.org/0000-0001-9181-615X

Hanna Karakuła - Juchnowicz ${ }^{1}$ ADE, https://orcid.org/0000-0002-5971-795X

${ }^{1}$ I Department of Psychiatry, Psychotherapy and Early Intervention, Medical University of Lublin

${ }^{2}$ Independent Public Hospital named John of God in Lublin

${ }^{3}$ II Department of Psychiatry and Psychiatry Rehabilitation, Medical University of Lublin

\begin{abstract}
Summary
\section{Introduction}

Sleep paralysis (SP) is a condition that widely occurs among people all over the world. It has been known for thousands of years and is rooted in the culture of many countries. It arouses strong emotions, though still little is known about it. The clinical picture of the disorder can be very diverse. It is often accompanied by hypnopompic and hypnagogic hallucinations, somatic complaints and the feeling of intense anxiety. A feeling of paralysis in the body with inhibited consciousness is always observed with the experience. SP pathophysiology is not fully understood, however, most theories explaining this phenomenon are based on the assumption that it results from dysfunctional overlap of REM sleep and wakefulness. It is experienced by healthy people, but it is more often associated with somatic and mental disorders, which is why it is becoming an object of interest for researchers.
\end{abstract}

\section{Aim}

The aim of this work is to present the most important information about the disorder known as sleep paralysis - its history, cultural context, pathophysiology, prevalence, symptomatology, coexistence with other somatic and mental disorders as well as diagnostics and available forms of prevention and treatment.

\section{Materials and methodology}

The available literature was reviewed using the Google Scholar bibliographic databases searching the following keywords: sleep paralysis, REM sleep parasomnias, sleep disorder, night terrors and time descriptors: 1980-2018.

\section{Results}

1. Sleep paralysis has already been described in antiquity, and interpretations related to its occurrence are largely dependent on culture and beliefs.

2. Symptomatology of the disorder is very diverse: both mental and somatic symptoms are present.

3. The pathophysiology of the disorder has not been fully explained. The basis of most theories regarding sleep paralysis is the assumption that it results from the dysfunctional overlap of REM sleep and wakefulness.

4. The prevalence of SP at least once in a lifetime is $7.6 \%$ in the general population, although it is estimated that it is much more frequent in people with various mental and somatic disorders.

5. Treatment of SP is associated with a change in lifestyle and the use of pharmacotherapy and psychotherapy.

Keywords: Sleep Paralysis, REM Sleep Parasomnias, Sleep Disorder, Night Terrors 


\section{Streszczenie}

\section{Wstęp}

Paraliż senny (PS) jest stanem występującym powszechnie u ludzi na całym świecie, znanym od tysięcy lat, zakorzenionym w kulturze wielu krajów, budzącym silne emocje, choć wciąż mało poznanym. Kliniczny obraz zaburzenia może być bardzo różnorodny, często towarzyszą mu halucynacje hipnopompiczne, hipnagogiczne, dolegliwości somatyczne a także uczucie silnego lęku. Zawsze występuje uczucie paraliżu ciała przy zahamowanej świadomości. Patofizjologia PS nie jest do końca poznana, jednak większość teorii wyjaśniających to zjawisko opiera się na założeniu, że wynika on z nieprawidłowego nakładania się fazy snu REM oraz stanu czuwania. Doświadczają go ludzie zdrowi, ale znacząco częściej towarzyszy on zaburzeniom somatycznym i psychicznym, dlatego coraz częściej staję się on przedmiotem zainteresowania badaczy.

\section{Cel}

Celem niniejszej pracy jest przedstawienie najważniejszych informacji dotyczących zaburzenia jakim jest paraliż senny - jego historii, kontekstu kulturowego, patofizjologii, rozpowszechnienia, symptomatologii, współwystępowania z innymi zaburzeniami somatycznymi i psychicznymi oraz diagnostyki i dostępnych form zapobiegania i leczenia.

\section{Materiał i metoda}

Dokonano przeglądu dostępnej literatury korzystając z baz bibliograficznych Google Scholar wprowadzając słowa klucze: sleep paralysis, REM sleep parasomnias, sleep disorder, night terrors oraz deskryptory czasowe: 1980 - 2018.

\section{Wyniki}

1. Paraliż senny został opisany już w starożytności, a interpretacje związane z jego występowaniem w dużym stopniu są zależne od kultury i wierzeń.

2. Symptomatologia zaburzenia jest bardzo różnorodna: obecne są zarówno objawy z kręgu psychicznego, jak somatycznego.

3. Patofizjologia zaburzenia nie została w pełni wyjaśniona. Podstawą większość teorii dotyczących paraliżu sennego jest założenie, że wynika on z dysfunkcyjnego nakładania się fazy snu REM i stanu czuwania.

4. Rozpowszechnienie PS chociaż raz w życiu wynosi 7,6\% w populacji ogólnej, choć szacuje się, że jest znacznie częstszy u osób z różnymi zaburzeniami psychicznymi i somatycznymi.

5. Leczenie PS wiąże się ze zmianą stylu życia oraz stosowaniem farmakoterapii i psychoterapii.

Słowa kluczowe: Paraliż senny, parasomnie fazy snu REM, zaburzenia snu, koszmary senne

\section{Introduction}

Sleep paralysis (SP) is a condition that widely occurs among people all over the world. It has been known for thousands of years and is rooted in the culture of many countries. It arouses strong emotions, though still little is known about it. It is experienced by healthy people, but it is more often associated with somatic and mental disorders, which is why it is becoming an object of interest for researchers.

Historically, the first known description of a sleep paralysis comes from the records of Hippocrates, who called the phenomenon "ephialtes", which in literal translation means "to lean upon" [1]. In the second century AD, the Greek philosopher and dream interpreter Artemidor from Daldis in his life's work "Oneirocritica" linked sleep paralysis with Pan - the Greek god of forests and pastures. According to the philosopher, a person experiencing paralysis was to experience a sexual act with Pan, which foretold the financial well-being of the dreamer [1]. During the Middle Ages, it was believed that the phenomenon was caused by the attack of demons: succubus and incubus. Demons taking the form of extremely beautiful women haunting men in their dreams and tempting them with sexual intercourse were called succubuses while the incubuses were their male counterparts [1].

The first scientific description of a sleep paralysis was made by Dutch physician Isbrand Van Diemerbroeck in 1664 . It was the case of a 50-year-old woman who experienced hypnagogic hallucinations with the simultaneous inability to move, the possibility to open her eyes, with chest tightness, a feeling of suffocation, choking and a demon's presence [2]. Two hundred years later, in 1876, an American neurologist and writer Silas Weir Mitchell described the phenomenon and called it "night palsy" - a night paralysis. The current 
term "sleep paralysis" was introduced by the British neurologist S.A. Kinnier Wilson in 1928 and defined it as a short, transient loss of volitional movements that appear when falling asleep or waking up [3].

\section{Aim}

The aim of this work is to present the most important information about the disorder known as sleep paralysis its history, cultural context, pathophysiology, prevalence, symptomatology, coexistence with other somatic and mental disorders as well as diagnostics and available forms of prevention and treatment.

\section{Methodology}

The available literature was reviewed using the Google Scholar bibliographic databases searching the following keywords: sleep paralysis, REM sleep parasomnias, sleep disorder, night terrors and time descriptors: 1980-2018.

In order to achieve transparency, the work is divided into sub-sections, which, in turn, include: 1. definitions and symptomatologies of sleep paralysis, 2. cultural influence and folk interpretations of sleep paralysis, 3. pathophysiologies. Next, sub-section 4 . the prevalence of paralysis and 4.1 co-occurrence with mental disorders, 4.2 co-occurrence with somatic diseases, 4.3 relationship of sleep paralysis with hypertension and panic attacks. Lastly, 5. diagnostics and 6 . prevention and treatment of sleep paralysis are presented.

\section{Definition and symptomatology}

Sleep paralysis (SP) is a phenomenon that can occur during the transition from sleep to wakefulness or upon falling asleep [4]. It consists of the inability to move which is accompanied by conscious awareness. Most skeletal muscles are paralyzed, although the function of the eye and diaphragm muscles is usually preserved [3]. The phenomenon usually lasts from a few seconds up to several minutes. Sometimes it is accompanied by hypnagogic and hypnopompic hallucinations [2,3,5,6]. Occasionally, it can occur in healthy people and in such cases it is called isolated sleep paralysis. More often, however, it appears in connection with various mental and somatic disorders. Genetic predisposition to the occurrence of SP has also been proven [7]. The International Classification of Sleep Disorders (ICSD-3) has included Recurrent Isolated Sleep Paralysis in the group of parasomnias associated with the REM phase.
People experiencing sleep paralysis most often report an inability to move their body while being awake $[3,8]$. The paralysis generally does not affect the muscles that move the eyeballs and the diaphragm [3], although in some cases breathing was inhibited [3]. The eyes of a person experiencing SP are usually closed, but the descriptions clearly indicate the possibility to open eyes $[2,6]$. People experiencing SP often try to fight for movement and have the impression that if they manage to move, the paralysis will pass [3]. Reportedly, even delicate external stimuli such as the touch of the hand or calling the patient by name lift the paralysis [3]. SP is usually accompanied by strong anxiety associated with experiencing this condition. Often, there is a sense of someone's presence in the immediate vicinity, described as feeling "an evil power" or "bad presence", which most likely significantly increases anxiety. Breathing difficulties and increased heart rate are also present. This may be accompanied by the occurrence of visual, auditory or cenesthetic hallucinations $[2,3,6]$. The subject of the hallucinations is usually a sinister figure described as a shadow, a demon - succubus or incubus, a witch, or a space alien, depending on the cultural affiliation of a given person $[2,6,9,10,11,12,13]$. Complex hallucinations in which the figure seen speaks to a paralyzed person or makes other sounds can occur. Steps or other noises can also be heard. A popular motive is the feeling of chest or throat tightness caused by a sinister figure that sits down on the chest or lies on top of the paralyzed person, abusing them sexually. It sometimes happens that the person experiencing SP has the impression that their body is levitating [6].

\section{The influence of culture and folk interpretations of sleep paralysis}

Although the documented case descriptions of SP seem to be very consistent, depending on the country, culture and religion, sleep paralysis is perceived and interpreted differently. Formerly, its occurrence was associated with supernatural powers. In some places on earth it is still considered a magical phenomenon.

In Egypt, almost half of people who experienced sleep paralysis believe that it was caused by the djinns (spirits of the Muslim religion). To protect themselves against successive episodes people use the help of healers, priests and undertake protective measures such as reciting the Koran, ritual prayers, or reading the Koran over water while simultaneously pouring the water on themselves [9].

In Japan, sleep paralysis is called "Kanashibari" - which means binding with a metal rope. The name is derived from the old belief that sleep paralysis is caused by the magic of 
Fudoh-Myohoh - a Buddhist god that Buddhist monks used to paralyze people as if they were bound by metal ropes [10]. In China, a part of the people experiencing the phenomenon also attribute it to the actions of supernatural powers believing that paralysis is caused by ghost oppression [11].

"Old Hag Phenomenon" is a traditional interpretation of sleep paralysis in Newfoundland. According to folk beliefs, the whole phenomenon is attributed to the visit of an old witch who comes to overworked people or to the victim of other people's hostile feelings [11].

In the south-eastern part of Brazil, according to folk beliefs, "Pisadeira" is responsible for a sleep paralysis - a witch with long nails who lurks on rooftops at night and tramples on the chest of those who sleep on a full stomach on their back [11].

In Italy, the phenomenon is called "Pandafeche" and 38\% of people who have been examined who experienced sleep paralysis believe that it was caused by supernatural beings such as demonic witches and ghosts that look like terrifying humanoid cats [12].

In some areas of the US, sleep paralysis is interpreted as an "alien abduction" [13].

The literature on the subject describes many other folk interpretations of sleep paralysis. A multitude of different interpretations of the phenomenon shows a strong influence of beliefs and culture on the course and nature of this experience.

\section{Pathophysiology}

Unfortunately, the pathophysiology of SP has not been thoroughly investigated. There are theories that try to explain the pathomechanism of this state. The basis of most theories regarding sleep paralysis is the assumption that it belongs to parasomnia and that it is a phenomenon resulting from the dysfunctional overlap of REM sleep and wakefulness.

During the REM sleep cycle, the dorsolateral part of the pons as well as the ventromedial medulla of the cortex reduces skeletal muscle tone by inhibiting the motor neurons by means of two neurotransmitters, $\gamma$-aminobutyric acid and glycine [14]. Atonia, however, does not refer to respiratory and oculomotor muscles that are active in this phase of sleep, and consciousness is abolished. During SP, there is conscious awareness despite the still active motor activity inhibition [3]. Polysomnographic studies have found that people who experience sleep paralysis have shorter REM latencies than normal along with shortened NREM and REM sleep cycles, and REM sleep fragmentation [15]. The study confirms the observation that disruption of regular sleep patterns can trigger an episode of sleep paralysis because REM sleep fragmentation commonly occurs when sleep patterns are disturbed and has now been noted in combination with sleep paralysis [15].

Another theory concerns the disturbances of activation of the neurotransmitters serotonin and acetylcholine during the REM sleep cycle [6]. Presumably, REM sleep is generated by neurons of the lateral part of the reticularis pontis oralis nucleus (RPO), located at the ventral portion of the locus coeruleus in the reticular formation. RPO and the lateral dorsal tegmental (LDT) nucleus, pedunculopontine tegmental nucleus (PPT) together form a group of neurons called REM-on (they completely inhibit monoamine secretion: serotonin, noradrenaline and histamine, which allows for completely unsuppressed cholinergic activity, the same as in the waking state) [16]. The dominance of REMon cells increases the level of acetylcholine, which inhibits the secretion of norepinephrine that results in muscle atony. It also inhibits histamine that results in the loss of consciousness. REM-off neurons are noradrenergic neurons of the locus coeruleus and serotonergic raphe nuclei. The alternating activity of REM-on and REM-off neurons determines the beginning and end of the REM sleep phase. Sleep paralysis can be a reflection of the abnormalities of REM-on and REM-off neurons and the neurotransmitters that occur there. This may be related to the hyperactivity of REM-on neurons or to the low activity of the REM-off cell population [6].

The mechanism of hallucination during the SP generates a lot of interest. There is a division of hallucinations associated with SP into three types: "Intruder", "Incubus" and "Unusual bodily experiences" [6]. The type of "Intruder" is characterized by a feeling of fear or unidentified unpleasant presence accompanied by auditory and visual hallucinations. The type "Incubus" refers to the feeling of pressure on the chest and dyspnoea. "Unusual bodily experiences" include the feeling of ascending and exiting the body (OBE, Outof-Body Experience). There was a correlation between "Intruder" and "Incubus" hallucinations [6]. These two types of hallucinations are thought to be associated with sudden entry and exit from the REM sleep phase. The third type of hallucination explains the hypothesis according to which the feeling of leaving the body during SP is caused by altered nerve processing in the temporoparietal cortex areas, which participate in the integration of visual, auditory, vestibular and proprioceptive information, coding the images of the body and its reception in the self [17]. 


\section{Prevalence}

The prevalence rate of SP varies and depends on many factors. Research shows that $7.6 \%$ of the total population experienced this state at least once [18]. A higher prevalence was noted among students - 28.3\% [18], representatives of national minorities living in the United States: African Americans - 40.2\%, Asians - 31\%, Spaniards - 11.3\% [18] and people suffering from various diseases both physical and mental. Little research has been done in Europe on the prevalence of SP. The lowest frequency occurrence of the phenomenon in the general population was noted in Germany 2.35\% [19], significantly more in Spain 20\% [20] and Denmark 25\% [21]. A survey conducted among Irish students showed that $19.9 \%$ of them experienced SP [22].

\subsection{Co-occurrence with mental disorders}

The occurrence of sleep paralysis was found in $31.9 \%$ of psychiatric patients [18]. In addition, numerous studies have led to the identification of mental disorders in which SP occurs much more frequently than in the general population. The first disorder that should be mentioned is narcolepsy. Sleep paralysis, one of its main symptoms, as its occurrence with this disease varies between 17 and 50\% depending on the study [23]. Other psychiatric disorders in which SP is much more common are anxiety disorders such as panic disorder $-20.8 \%$ to $30.6 \%$, social phobia $-22.2 \%$, generalized anxiety disorder $-15.8 \%$ [24]. Research confirms the relationship between post-traumatic stress disorder and more frequent occurrence of sleep paralysis. For example, the Ramsawh study results (2008) show that $27.8 \%$ of people who were diagnosed with post-traumatic stress disorder experienced sleep paralysis. According to another study, conducted among Cambodian refugees hospitalized for post-traumatic stress disorder, the incidence of sleep paralysis during the last year was 76\% [25]. In addition, among people who experienced sexual abuse in their childhood, not only was occurrence of observed SP higher, but also prevalence of paralysis accompanied by a stronger level of anxiety than in the general population [26]. Among psychiatric patients, SP is much less common in people suffering from depression, schizophrenia, schizoaffective disorder and bipolar disorder - SP appeared in about $15 \%$ of respondents with these diseases, mainly in men [5].

\subsection{Co-occurrence with somatic diseases}

There are premises of the correlation of poor somatic state with an increased probability of SP. The most important contributing factors to the occurrence of SP are: poor sleep hygiene, physical and mental fatigue, bad eating habits, alcohol consumption $[7,8,27]$, shift work and diseases such as: arterial hypertension $[8,28]$, restless legs syndrome [29], obstructive sleep apnea (OSA) [8, 30], Wilson's disease [31.32], idiopathic hypersomnia [33], sleep-deprivation syndrome [4].

The consumption of a large amount of caffeine and smoking cigarettes is also considered a potential risk factor for SP, due to the fact that caffeine and nicotine are responsible for poor sleep quality [34,35]. Nevertheless, the influence of these factors has not been confirmed by studies [7].

\subsection{Panic attacks/hypertension/sleep paralysis}

Studies have confirmed that isolated sleep paralysis, panic attacks and anxiety disorder with panic attacks are common disorders among African Americans suffering from hypertension. A pilot study of 31 patients with elevated blood pressure showed that $41.9 \%$ had isolated sleep paralysis, $35.5 \%$ had panic attacks, and $9.7 \%$ had anxiety disorder with panic attacks. It was also shown that patients with hypertension and isolated sleep paralysis were more susceptible to panic attacks than those with hypertension without an insulated sleep paralysis. This information indicates a close relationship between hypertension and the occurrence of sleep paralysis and seizure disorders [28].

\section{Diagnostics}

Recurrent Isolated Sleep Paralysis is coded G47.51 in the International Classification of Sleep Disorders (ICSD-3) [4]. Its diagnosis is based on a clinical picture and the exclusion of other potential disorders associated with sleep paralysis (anxiety disorder, post-traumatic stress disorder, migraine, obstructive sleep apnea, with particular emphasis on narcolepsy, which is often accompanied by sleep paralysis) [29]. In the Eleventh edition of the International Classification of Diseases (ICD-11), Recurrent Isolated Sleep Paralysis (RISP) has been qualified as a parasomnia associated with the REM sleep phase, code 7B01.1 [36]. In the $V$ version of the Diagnostic and Statistical Manual of Mental Disorders of the American Psychiatric Association (DSM-5) RISP is not included, but it can be marked as 307.40 (unspecified sleep-wake disorder) or 307.49 (other specified sleep-wake disorder) [37].

There are many questionnaires to help diagnose sleep paralysis as well as its severity and course. Examples of such tools include: "Sleep Paralysis Experiences and Phenomenology Questionnaire", "Fearful Isolated Sleep Paralysis Interview" [38], "Unusual Sleep Experiences Questionnaire" [39], "Waterloo Unusual Sleep Experiences Questionnaire" [6], "Munich Parasomnia Screening" [40]. 


\section{Prevention and treatment}

The most important thing in the prevention and treatment of sleep paralysis is the elimination of factors causing or contributing to the occurrence of SP such as insufficient sleep, irregular sleep schedule, stress, excessive physical fatigue, stimulants (coffee, nicotine and alcohol) and avoiding sleeping in the supine position [41].

Pharmacological treatment is used only in the most severe cases [42] and in the case of SP accompanying narcolepsy. Drugs belonging to tricyclic antidepressants and selective serotonin reuptake inhibitors are used [42]. Their hypothetical mechanism of action is based on the suppression of REM sleep. These drugs are commonly used to treat other symptoms of narcolepsy. To date, efficacy in reducing the number of SP episodes has been reported for clomipramine (25-50 mg), imipramine (25-150 mg/dg), protriptyline (10-40 $\mathrm{mg})$ and desmethylimipramine (25-150 mg / dg) [43]. A beneficial effect in the reduction of SP symptoms was also observed after the use of fluoxetine (40-80 mg qd) [44] and femoxetine (600 mg) [45]. Relaxation and meditation techniques are also used to treat this disorder. One of the methods is Meditation - relaxation (MR), which is based on four stages:

1. Re - evaluate the importance of the attacks,

2. Psychological and emotional distance,

3. Meditation that focuses internal attention,

4. Muscle relaxation.

\section{Wstęp}

Paraliż senny (porażenie przysenne, paraliż przysenny) jest stanem występującym powszechnie u ludzi na całym świecie, znanym od tysięcy lat, zakorzenionym w kulturze wielu krajów, budzącym silne emocje lecz wciąż mało poznanym. Doświadczają go ludzie zdrowi ale znacząco częściej towarzyszy on zaburzeniom somatycznym i psychicznym, dlatego coraz częściej staję się on przedmiotem zainteresowania badaczy.

Historycznie pierwszy znany opis paraliżu sennego pochodzi z zapisów Hipokratesa, który nazywał zjawisko „ephialtes”, co w dosłownym tłumaczeniu oznacza „rzucić się na kogoś" [1]. W II wieku naszej ery grecki filozof i interpretator snów Artemidor z Daldis w dziele swojego życia „Oneirocritica” powiązał paraliż senny z Panem - greckim bogiem lasów i pól. Według filozofa osoba doświadczająca paraliżu miała doznać aktu seksualnego z Panem, co zapowiadała pomyślność finansową śniącego
The effectiveness of this type of therapy has not yet been confirmed in randomized clinical trials [46].

\section{Conclusion}

Sleep paralysis has already been described in antiquity. Its interpretations are to a large extent dependent on culture and beliefs. Symptomatology of the disorder is very diverse. There are both psychological symptoms in the form of hypnopompic and hypnagogic hallucinations as well as somatic ones. In addition, most episodes are accompanied by intense anxiety. The pathophysiology of the disorder has not been fully explained. The basis of most theories regarding sleep paralysis is the assumption that it belongs to parasomnia and is a phenomenon resulting from the dysfunctional overlap of REM sleep and wakefulness. Research indicates that $7.6 \%$ of the general population experienced SP at least once. However, it is much more common in people with various mental or somatic disorders. Certain social groups also experience sleep paralysis significantly more often. There are SP risk factors related to leading an unhealthy lifestyle, which include certain stimulants and poor sleep hygiene. Diagnosis is based mainly on the clinical picture. The prevention sleep paralysis can be achieved with a change in lifestyle, as well as with the use pharmacotherapy and psychotherapy. Due to the fact that pharmacological treatment is reserved only for the most serious cases and SP accompanying narcolepsy, the effectiveness of possible methods of psychotherapy has not been clinically confirmed. It is necessary to continue the research. At present, no research on the prevalence and characteristics of SP has been published in Poland. There is a need for research to assess the scale of the problem in our country.

[1]. W okresie średniowiecza wierzono, że zjawisko spowodowane jest napaścią demonów: sukubów i inkubów. Sukkubami nazywano demony przybierające postać niezwykle pięknych kobiet nawiedzających mężczyzn we śnie i kuszące ich współżyciem seksualnym natomiast inkubami były ich męskie odpowiedniki [1].

Pierwszego naukowego opisu paraliżu sennego w Europie dokonał holenderski lekarz Isbrand Van Diemerbroeck w 1664r. Ów zapis dotyczył przypadku 50 - letniej kobiety, która doświadczała omamów hipnagogicznych, z jednoczesną niemożnością poruszania się, z zachowaną możliwością otwarcia oczu, z odczuwaniem ucisku klatki piersiowej, uczuciem duszenia się, dławienia oraz poczuciem obecności demona [2]. Dwieście lat później, w roku 1876 amerykański neurolog i pisarz Silas Weir Mitchell opisał zjawisko oraz nazwał je "night palsy" porażenie nocne. Obowiązujący współcześnie termin „paraliż senny” (z ang. sleep paralysiss) wprowadził brytyjski neurolog S.A. Kinnier Wilson w 1928 i zdefiniował 
go jako krótką, przemijającą utratę ruchów wolicjonalnych, które pojawiają się podczas zasypiania lub przebudzania się [3].

\section{Cel}

Celem niniejszej pracy jest przedstawienie najważniejszych informacji dotyczących zaburzenia jakim jest paraliż senny - jego historii, kontekstu kulturowego, patofizjologii, rozpowszechnienia, symptomatologii, współwystępowania z innymi zaburzeniami somatycznymi i psychicznymi, diagnostyki i dostępnych form zapobiegania i leczenia.

\section{Metoda}

Dokonano przeglądu dostępnej literatury korzystając z baz bibliograficznych Google Scholar wprowadzając słowa klucze: paraliż senny, sleep paralysis, REM sleep parasomnias, sleep disorder, night terrors oraz deskryptory czasowe: 1980-2018.

Celem uzyskania przejrzystości praca została podzielona na podrozdziały, które kolejno obejmują: 1. definicje i symptomatologie paraliżu sennego, 2. wpływ kultury oraz ludowe interpretacje paraliżu sennego, 3. patofizjologie. Następnie została omówiona 4. częstość występowania paraliżu oraz 4.1 współwystępowanie z zaburzeniami psychicznymi, 4.2 współwystępowanie z chorobami somatycznymi, 4.3 związek paraliżu sennego z nadciśnieniem tętniczym i napadami paniki. Na końcu została przedstawiona 5. diagnostyka oraz 6. zapobieganie i leczenie paraliżu sennego.

\section{Definicja i symptomatologia}

Paraliż senny (PS) jest zjawiskiem, które może pojawić się podczas przechodzenia ze snu do stanu czuwania, bądź podczas zasypiania [4]. Polega na niemożności poruszenia się, której towarzyszy włączona świadomość. Większość mięśni szkieletowych zostaje porażona, aczkolwiek funkcja mięśni gałek ocznych i przepony najczęściej pozostaje zachowana [3]. Zjawisko trwa przeważnie od kilku sekund do paru minut. Czasami towarzyszą mu halucynacje hipnagogiczne i hipnopompiczne $[2,3,5,6]$. Sporadycznie może występować u ludzi zdrowych i w takich przypadkach nazywany jest izolowanym paraliżem sennym. Częściej natomiast pojawia się $\mathrm{w}$ związku z różnymi zaburzeniami psychicznymi i somatycznymi. Udowodniono również genetyczne predyspozycje do występowania PS [7]. Międzynarodowa klasyfikacji snu (ICSD-3) umieściła Nawracający Izolowany Paraliż Senny (ang. Recurrent Isolated Sleep Paralysis) w grupie parasomni związanych z fazą REM.
Ludzie doświadczający paraliżu sennego najczęściej zgłaszają niemożność poruszenia ciałem przy całkowitym wybudzeniu [3, 8]. Porażenie na ogół nie dotyczy mięśni poruszających gałkami ocznymi oraz przepony [3], choć w niektórych przypadkach czynność oddechowa bywała zahamowana [3]. Oczy osoby doświadczającej PS przeważnie są zamknięte, jednak opisy wyraźnie wskazują na możliwość otwierania oczu [2, 6]. Osoby doświadczające PS często próbują toczyć walkę o ruch i mają wrażenie, że jeśli uda im się poruszyć, to paraliż minie [3]. Podobno nawet delikatne bodźce zewnętrzne takie jak np. dotyk ręki, czy wezwanie pacjenta po imieniu, znoszą paraliż [3]. Doświadczeniu PS na ogół towarzyszy silny lęk związany z przeżywaniem tego stanu. Często zdarza się poczucie czyjejś obecności w bezpośrednim otoczeniu, nazywane odczuwaniem „złej siły“ czy „złej obecności”, co najprawdopodobniej istotnie nasila lęk. Występują trudności z oddychaniem i przyspieszone bicie serca. Towarzyszyć temu może wystąpienie omamów wzrokowych, słuchowych czy cenestetycznych $[2,3$, 6]. Tematem omamów jest najczęściej złowroga postać opisywana jako cień, demon - sukkub lub inkub, wiedźma, kosmita, zależnie od przynależności kulturowej danej osoby $[2,6,9,10,11,12,13]$. Zdarzają się omamy złożone, w których widziana postać mówi do sparaliżowanej osoby, bądź wydaje inne dźwięki. Mogą być także słyszane kroki, czy inne odgłosy. Popularnym motywem jest odczucie ucisk klatki piersiowej czy gardła przez złowrogą postać, która siada na klatce piersiowej bądź kładzie się na sparaliżowanej osobie, wykorzystując ją seksualnie. Zdarza się, ze osoba doświadczająca PS ma wrażenie jakby jej ciało lewitowało [6].

\section{Wpływ kultury oraz ludowe interpretacje paraliżu sennego}

Chociaż udokumentowane opisy przypadków SP wydają się być bardzo spójne, to w zależności od kraju, kultury oraz religii paraliż senny jest różnie odbierany i interpretowany. Dawniej jego występowanie wiązano z działaniem nadprzyrodzonych mocy. W niektórych miejscach na ziemi nadal uważany jest za zjawisko magiczne.

W Egipcie niemalże połowa ludzi, którzy doświadczyli paraliżu sennego uważa, że był on spowodowany działaniami dżinów (duchów wywodzących się z religii muzułmańskiej). Ludzie aby uchronić się przed kolejnymi epizodami korzystają z pomocy uzdrowicieli, kapłanów oraz podejmują działania ochronne takie jak recytowanie Koranu, modlitwy rytualne, czytanie Koranu nad woda $\mathrm{z}$ równoczesnym polewaniem się wodą [9].

W Japonii paraliż senny nazywany jest „Kanashibari”, - co oznacza wiązanie metalową liną. Nazwa ta wywodzi się z dawnych wierzeń, według których paraliż senny spowodowany jest magią Fudoh - Myohoh - buddyjskiego 
boga, której używali buddyjscy mnisi paraliżowania ludzi tak jak by byli oni związani metalowymi linami [10]. W Chinach również cześć ludzi doświadczających zjawiska przypisuje je działaniom nadprzyrodzonych mocy, uważają oni że paraliż wywołany jest opresją duchów [11].

„Old Hag Fenomen” to tradycyjna interpretacja paraliżu sennego w Nowej Fundlandii. Całe zjawisko według wierzeń ludowych jest przypisywane wizycie starej wiedźmy, która przychodzi do osób przemęczonych lub do ofiary wrogich uczuć innej osoby [11].

W południowo - wschodniej części Brazylii zgodnie z ludowymi wierzeniami za paraliż senny odpowiedzialna jest „Pisadeira”- wiedźma z długimi paznokciami, która czai się nocą na dachach i depcze po klatce piersiowej tych ludzi, którzy śpią z pełnym żołądkiem na plecach [11].

We Włoszech zjawisko nazywane jest „Pandafeche” a 38\% zbadanych ludzi, którzy doświadczyli paraliżu sennego uważa, że był on spowodowany przez nadnaturalne istoty takie jak demoniczne czarownice i duchy wyglądające jak przerażające humanoidalne koty [12].

W niektórych obszarach USA paraliż senny interpretuje się jako „uprowadzenie przez kosmitów” [13].

Literatura przedmiotu opisuje jeszcze wiele innych ludowych interpretacji paraliżu sennego. Mnogość różnorodnych interpretacji zjawiska pokazuje silny wpływ wierzeń oraz kultury na przebieg i charakter tego doświadczenia.

\section{Patofizjologia}

Patofizjologia PS wciąż niestety nie została dokładnie zbadana. Istnieją teorie, próbujące wyjaśnić patomechanizm tego stanu. Podstawą większość teorii dotyczących paraliżu sennego jest założenie, że należy on do parasomnii i że jest zjawiskiem wynikającym z dysfunkcyjnego nakładania się fazy snu REM i stanu czuwania.

Podczas fazy snu REM, okolica grzbietowo-boczna mostu oraz brzuszno - przyśrodkowa rdzenia redukuje napięcie mięśni szkieletowych poprzez hamowanie rdzeniowych neuronów motorycznych za pomocą dwóch przekaźników, kwasu $\gamma$ - aminomasłowego oraz glicyny [14]. Atonia nie odnosi się jednak do mięśni oddechowych oraz okoruchowych, które są aktywne w tej fazie snu, a świadomość jest zniesiona. Podczas PS zostaje włączona świadomość, pomimo wciąż aktywnego hamowania motorycznego [3]. Badania polisomnograficzne wykazały, że osoby, które doświadczają paraliżu sennego mają krótszą latencje fazy REM niż normalnie, wraz ze skróceniem cykli snu NREM i REM oraz fragmentacją snu REM [15]. Badanie to potwierdza obserwację, że zakłócenie regularnych wzorców snu może wywołać epizod paraliżu sennego, ponieważ fragmentacja snu REM zwykle występuje, gdy wzorce snu są zakłócane i obecnie obserwowano ją w połączeniu z paraliżem snu [15].

Inna teoria dotyczy zaburzeń aktywacji neuroprzekaźników serotoniny i acetylocholiny podczas fazy snu REM [6]. Prawdopodobnie sen REM jest generowany przez neurony bocznej części jądra przedniego mostu (RPO), zlokalizowane przy brzusznej części miejsca sinawego w tworze siatkowatym mostu. RPO oraz jądro nakrywkowo boczne (LDT), jądro nakrywkowe konarowo-mostowe (PPT) wspólnie tworzą populację neuronów nazywanych REM - on (hamują one całkowicie wydzielanie monoamin: serotoniny, noradrenaliny i histaminy, co pozwala na niczym nieograniczoną aktywność cholinergiczną, taką samą jak w stanie czuwania) [16]. Dominacja komórek REM-on powoduje zwiększenia poziomu acetylocholiny co hamuje wydzielanie noradrenaliny co skutkuje atonia mięśni, a zahamowanie histaminy utratą świadomości. Neurony REM-off to noradrenergiczne neurony miejsca sinawego oraz serotoninergiczne jąder szwu. Naprzemienna aktywność z neuronów REM-on i REM-off decyduje o początku i końcu fazy snu REM. Paraliż senny może być odzwierciedleniem nieprawidłowości w pracy neuronów REM-on i REM-off oraz neuroprzekaźników tam występujących. Związane może to być z nadaktywnością neuronów REM-on albo za niską aktywnością populacji komórek REM-off [6].

Mechanizm powstawania halucynacji podczas PS budzi liczne zainteresowania. Istnieje podział halucynacji związanych z SP na trzy typy: „Intruz”, „Inkubus" oraz „Niezwykłe doznania cielesne" [ 6].

Typ "Intruza" charakteryzuje się uczuciem strachu lub nieokreślonej nieprzyjemnej obecności, któremu towarzyszą halucynacje słuchowe i wzrokowe. Typ „Incubus" odnosi się do odczuwania nacisku na klatkę piersiową i uczucia duszności. "Niezwykłe doznania cielesne" obejmują uczucie unoszenia się oraz wychodzenia z ciała(OBE, ang. Out-ofBody Experience). Zaobserwowano korelację pomiędzy halucynacjami typu „Intruz” i „Inkubus” [6]. Uważa się, że te dwa typy halucynacji związane są z nagłym wejściem i wyjściem z fazy snu REM. Trzeci typ halucynacji tłumaczy hipoteza według, której uczucie opuszczania ciała podczas PS jest spowodowane zmienionym przetwarzaniem nerwowym w obszarach kory skroniowo - ciemieniowej, które uczestniczą w integracji informacji wzrokowej, słuchowej, przedsionkowej i proprioceptywnej, kodując obrazy ciała i jego odbieranie w jaźni [17].

\section{Występowanie}

Częstość występowanie PS jest różna i zależy od wielu czynników. Badania wskazują, że tego stanu doświadczyło chociaż raz 7,6\% ogółu populacji [18]. Większą częstość występowania zauważono wśród studentów - 28,3\% [18], 
przedstawicieli mniejszości narodowych zamieszkujących Stany Zjednoczone: Afroamerykanów - 40,2 \%, Azjatów - 31\%, Hiszpanów - 11,3 \% [18] oraz ludzi cierpiących na różne schorzenia zarówno fizyczne jak i psychiczne.

W Europie przeprowadzono niewiele badań dotyczących rozpowszechnienia PS. Najniższa częstość zjawiska w ogólnej populacji zauważono w Niemczech 2,35\% [19], znacząco więcej w Hiszpanii 20\% [20] oraz Dani 25\% [21]. Badanie przeprowadzone wśród Irlandzkich studentów wykazało, że 19,9\% z nich doświadczyło PS [22].

\subsection{Współwystępowanie z zaburzeniami psychicznymi}

Występowanie paraliżu sennego stwierdzono aż u 31,9\% pacjentów psychiatrycznych [18], a dodatkowo liczne badania pozwoliły na wyłonienie zaburzeń psychicznych, w których PS pojawia się znacznie częściej niż w populacji ogólnej. Na pierwszym miejscu należy tu wymienić narkolepsję, której jednym z głównych objawów jest właśnie paraliż senny, a jego występowanie w tej chorobie waha się między 17 a 50\% w zależności od badania [23]. Innymi zaburzeniami psychicznymi, w których PS występuje zdecydowanie częściej są zaburzenia lękowe takie jak zespół lęku napadowego - 20, 8\% do 30,6\%, fobia społeczna - 22,2\%, zaburzenie lękowe uogólnione - 15,8\% [24]. Wiele badań potwierdza związek pomiędzy zaburzeniem stresowym pourazowym, a częstszym występowaniem paraliżu sennego. Dla przykładu można tu podać wyniki badań Ramsawh (2008 r), które wskazują, że 27,8\% osób którym zdiagnozowano zespól stresu pourazowego doświadczyło paraliżu sennego. Według innego badania, przeprowadzonego wśród Kambodżańskich uchodźców hospitalizowanych $\mathrm{z}$ powodu zaburzenia stresowego pourazowego częstość występowania paraliżu sennego w ciągu ostatniego roku wyniosła 76\% [25]. Dodatkowo u osób, które w dzieciństwie doświadczyły przemocy seksualnej zaobserwowano nie tylko większą częstość występowania PS ale także wyższą częstotliwość napadów paraliżu, którym towarzyszył silniejszy poziom lęku niż w populacji ogólnej [26]. Spośród pacjentów psychiatrycznych, PS zdecydowanie rzadziej występuje u osób cierpiących $\mathrm{z}$ powodu depresji, schizofrenii, zaburzenia schizoafaktywnego oraz choroby afektywnej dwubiegunowej - PS pojawił się u ok. $15 \%$ badanych $\mathrm{z}$ wymienionymi schorzeniami, głównie u mężczyzn [5].

\subsection{Współwystępowanie z chorobami somatycznymi}

Istnieją przesłanki o korelacji złego stanu somatycznego ze zwiększonym prawdopodobieństwem wystąpieniem PS. Za najważniejsze czynniki sprzyjające występowaniu PS uważa się: niewłaściwą higienę snu, zmęczenie fizyczne i psychiczne, złe nawyki żywieniowe, spożywanie alkoholu [7, 8, 27], pracę zmianową oraz choroby takie jak: nadciśnienie tętnicze [8,28], zespół niespokojnych nóg [29], obturacyjny bezdech senny (OBS) [8,30], choroba Wilsona [31, 32], idiopatyczna hipersomnia [33], zespół niedoboru snu [4].

Spożywanie dużej ilości kofeiny oraz palenie papierosów również uznane jest za potencjalny czynnik ryzyka PS, ze względu na to, że kofeina i nikotyna są odpowiedzialne za niską jakość snu [34,35] mimo to wpływ tych czynników nie został potwierdzony przez badania [7].

\subsection{Napady paniki/nadciśnienie tętnicze/paraliż senny}

Badania potwierdziły iż izolowany paraliż senny, ataki paniki oraz zaburzenie lękowe $\mathrm{z}$ napadami paniki są powszechnymi zaburzeniami wśród Afroamerykanów chorujących na nadciśnienie tętnicze. Badanie pilotażowe z 31 pacjentów z podwyższonym ciśnieniem krwi wykazało, że 41,9\% miało izolowany paraliż senny, 35,5\% ataki paniki, 9,7\% zaburzenie lękowe $\mathrm{z}$ napadami paniki. Wykazano również, że pacjenci z nadciśnieniem tętniczym i izolowanym paraliżem sennym byli bardziej narażeni na ataki paniki niż chorzy z nadciśnieniem tętniczym bez izolowanego paraliżu sennego. Informacje te wskazują na ścisłą zależność pomiędzy nadciśnieniem a wystąpieniem paraliżu sennego oraz zaburzeń napadowych [28].

\section{Diagnostyka}

Nawracający Izolowany Paraliż Senny w Międzynarodowej Klasyfikacji Zaburzeń Snu (ICSD-3) zakodowany jest G47.51 [4] Jego rozpoznanie oparte jest na obrazie klinicznym oraz na wykluczeniu innych potencjalnych schorzeń przebiegających z paraliżem sennym (zaburzenia lękowe, zespół stresu pourazowego, migrena, obturacyjny bezdech senny, ze szczególnym uwzględnieniem narkolepsji, której paraliż senny często towarzyszy) [29]. W Jedenastym wydaniu Międzynarodowej Klasyfikacji Chorób (ICD-11) Nawracający Izolowany Paraliż Senny (NIPS) został zakwalifikowany do parasomni związanych z fazą snu REM, oznaczony kodem 7B01.1 [36]. W V wersji Klasyfikacji Zaburzeń Psychicznych Amerykańskiego Towarzystwa Psychiatrycznego (DSM-5) NIPS nie jest ujęty, jednak można go oznaczać kodem 307.40 (unspecified sleep-wake disorder) lub 307.49 (other specified sleep - wake disorder) [37].

Istnieje wiele kwestionariuszu ułatwiających diagnostykę paraliżu sennego a także jego nasilenie i przebieg. Jako przykłady takich narzędzi można podać: "Sleep Paralysis Experiences and Phenomenology Questionnaire", "Fearful Isolated Sleep Paralysis Interview" [38], “Unusual Sleep Experiences Questionnaire" [39], "Waterloo Unusual Sleep Experiences Questionnaire" [6], 
“Munich Parasomnia Screening” [40].

\section{Zapobieganie i leczenie}

Największe znaczenie w zapobieganiu i leczeniu paraliżu sennego ma wyeliminowanie czynników wywołujących lub sprzyjających występowaniu PS takich jak: niewystarczająca ilość snu, nieunormowany harmonogram snu, stres, nadmierne zmęczenie fizyczne, używki (kawa, nikotyna i alkohol) oraz unikanie spania w pozycji na plecach [41].

Leczenie farmakologiczne jest stosowane tylko w najcięższych przypadkach [42] oraz w przypadku PS sennego towarzyszącego narkolepsji. Zastosowanie mają leki należące do trójcyklicznych leków przeciwdepresyjnych oraz selektywnych inhibitorów wychwytu zwrotnego serotoniny [42]. Ich hipotetycznym mechanizmem działania jest oparty na tłumieniu fazy snu REM. Leki te są powszechnie stosowane $\mathrm{w}$ leczeniu innych objawów narkolepsji. Dotychczas skuteczność w zmniejszeniu liczby epizodów PS odnotowano dla klomipraminy (25-50 mg), imipraminy (25-150 mg/dg), protryptyliny (10-40 mg) i desmetyloimipraminy $(25-150 \mathrm{mg} / \mathrm{dg})[8,43]$. Korzystny efekt $w$ redukcji objawów PS zaobserwowano także po zastosowaniu fluoksetyny (40-80 mg qd) [44] i femoksetyny (600 mg) [45]. Zastosowanie $\mathrm{w}$ leczeniu tego zaburzenia mają również techniki relaksacyjne i medytacyjne. Jedną z metod jest Meditation-relaxation (MR), która opiera się na czterech etapach:

1. Ponownej ocenie znaczenia ataków,

2. Psychologicznego i emocjonalnego dystansu,

3. Medytacji skupiającej uwagę wewnętrzną,

4. Rozluźnieniu mięśni.

Skuteczność tego rodzaju terapii nie ma jeszcze potwierdzenia w randomizowanych badaniach klinicznych [46].

\section{Podsumowanie}

Paraliż senny został opisany już w starożytności. Jego interpretacje są w dużym stopniu są zależne od kultury i wierzeń. Symptomatologia zaburzenia jest bardzo różnorodna. Obecne są zarówno objawy psychiczne w postaci halucynacji hipnopompicznych i hipnagogicznych jak i somatyczne. Dodatkowo większości epizodom towarzyszy silny lęk. Patofizjologia zaburzenia nie została w pełni wyjaśniona. Podstawą większość teorii dotyczących paraliżu sennego jest założenie, że należy on do parasomnii oraz jest zjawiskiem wynikającym z dysfunkcyjnego nakładania się fazy snu REM i stanu czuwania. Badania mówią, że PS pojawił się chociaż raz u 7,6\% populacji ogólnej, jednak jest znacznie częstszy u osób z różnymi zaburzeniami psychicznymi czy też somatycznymi. Niektóre grupy społeczne także istotnie częściej doświadczają paraliżu sennego. Istnieją czynniki ryzyka PS związane z nieprzestrzeganiem zdrowego stylu życia, do których należą niektóre używki oraz nieprawidłowa higiena snu. Diagnostyka oparta jest głównie na obrazie klinicznym. Zapobiegać paraliżowi sennemu można poprzez zmianę stylu życia, a także przy pomocy farmakoterapii i psychoterapii. Ze względu na to, że farmakologiczne leczenie zarezerwowane jest tylko dla najcięższych przypadków oraz PS towarzyszącemu narkolepsji a skuteczność możliwych metod psychoterapii nie została potwierdzona klinicznie konieczne jest kontynuowanie badań. Obecnie, na terenie polski nie zostały opublikowane badania dotyczące rozpowszechnia i charakterystyki PS. Istnieje potrzeba przeprowadzenia badań w celu oceny skali problemu na terenie naszego kraju.

\section{Conflict of interest}

The authors have declared no conflict of interest.

\section{References:}

1. de Sá JF, Mota-Rolim SA. Sleep paralysis in Brazilian folklore and other cultures: a brief review. Front Psychol. 2016 7;7:1294.

2. Kompanje EJ. 'The devil lay upon her and held her down' Hypnagogic hallucinations and sleep paralysis described by the Dutch physician Isbrand van Diemerbroeck (1609-1674) in 1664.J Sleep Res. 2008;17(4):464-7.

3. Ropper, A. H. (2016). Adams and Victor's principles of neurology. New York: McGraw-Hill Medical Pub. Division.

4. American Academy of Sleep Medicine. "International classification of sleep disorders-third edition (ICSD-3)." Darien, IL: American Academy of Sleep Medicine 2014.

5. Gangdev P, Dua V, Desjardins NIsolated sleep paralysis and hypnic hallucinations in schizophrenia. Indian J Psychiatry. 2015;57(4):383-5.

6. Cheyne J.A, Newby-Clark IR, Rueffer SD. Relations among hypnagogic and hypnopompic experiences associated with sleep paralysis. J Sleep Res. 1999 ;8(4):313-7.

7. Denis D, French CC, Rowe R, Zavos HM, Nolan PM, Parsons MJ et al. A twin and molecular genetics study of sleep paralysis and associated factors. J Sleep Res. 2015;24(4):438-46

8. Sharpless BA. A clinician's guide to recurrent isolated sleep paralysis. Neuropsychiatr Dis Treat. 2016;12:1761-7.

9. Jalal B, Simons-Rudolph J, Hinton DE.Explanations of sleep paralysis among Egyptian college students and the general population in Egypt and Denmark. Transcult Psychiatry. 2014;51(2):158-75.

10. Fukuda K, Miyasita A, Inugami M, Ishihara K.High prevalence of isolated sleep paralysis: Kanashibari phenomenon in Japan. Sleep. 1987;10(3):279-86.

11. Wing YK, Lee ST, Chen CN.Sleep paralysis in Chinese: ghost oppression phenomenon in Hong Kong Sleep. 1994;17(7):609-13.

12. Jalal B, Romanelli A, Hinton DECultural Explanations of sleep paralysis in Italy: the pandafeche attack and associated 
supernatural beliefs. Cult Med Psychiatry. 2015;39(4):651-64.

13. McNally RJ, Clancy SA.Sleep paralysis, sexual abuse, and space alien abduction. Transcult Psychiatry. 2005;42(1):113-22.

14. Brooks PL, Peever JH. Identification of the transmitter and receptor mechanisms responsible for REM sleep paralysis. J Neurosci. 2012;32(29):9785-95.

15. Björn WW., Schulz H. Recurrent isolated sleep paralysis: Polysomnographic and clinical findings. SomnologieSchlafforschung und Schlafmedizin. 2004;8(2):53-60.

16. Torontali ZA, Grace KP, Horner RL, Peever JH. Cholinergic involvement in control of REM sleep paralysis. J Physiol. 2014 ;592(7):1425-6.

17. Jalal B, Ramachandran VS. Sleep paralysis and "the bedroom intruder": The role of the right superior parietal, phantom pain and body image projection. Med Hypotheses. 2014;83(6):755-7.

18. Sharpless BA1, Barber JP. Lifetime prevalence rates of sleep paralysis: a systematic review. Sleep Med Rev. 2011;15(5):311-5.

19. Dahmen N, Kasten M, Müller MJ, Mittag K. Frequency and dependence on body posture of hallucinations and sleep paralysis in a community sample. J Sleep Res. 2002;11(2):179-80.

20. Alfonso Suárez S. Isolated sleep paralysis in patients with disorders due to anxiety crisis. Actas Luso Esp Neurol Psiquiatr Cienc Afines. 1991;19(1):58-61.

21. Jalal B, Hinton DE. Rates and characteristics of sleep paralysis in the general population of Denmark and Egypt. Cult Med Psychiatry. 2013;37(3):534-48.

22. O'Hanlon J, Murphy M, Di Blasi Z. Experiences of sleep paralysis in a sample of Irish university students. Ir J Med Sci. 2011;180(4):9179.

23. American Sleep Disorders Association. International classification of sleep disorders. Revised: Diagnostic and coding manual; 1994. [cytowana 20 lipca 2018]. Dostępna z: http://www. absm. org/ PDF/ICSD. pdf.

24. Otto MW, Simon NM, Powers M, Hinton D, Zalta AK, Pollack MH. Rates of isolated sleep paralysis in outpatients with anxiety disorders. J Anxiety Disord. 2006;20(5):687-93.

25. Hinton DE, Pich V, Chhean D, Pollack MH, McNally RJ.Sleep paralysis among Cambodian refugees: association with PTSD diagnosis and severity. Depress Anxiety. 2005;22(2):47-51.

26. Abrams MP, Mulligan AD, Carleton RN, Asmundson GJ. Prevalence and correlates of sleep paralysis in adults reporting childhood sexual abuse. J Anxiety Disord. 2008;22(8):1535-41.

27. Golzari SE, Ghabili K. Alcohol-mediated sleep paralysis: the earliest known description. Sleep Med. 2013;14(3):298

28. Bell CC, Hildreth CJ, Jenkins EJ, Carter C. The relationship of isolated sleep paralysis and panic disorder to hypertension." J Natl Med Assoc. 1988;80(3):289-94.

29. Ohayon MM, Zulley J, Guilleminault C, Smirne S. Prevalence and pathologic associations of sleep paralysis in the general population. Neurology. 1999 12;52(6):1194-200.

30. Hsieh SW, Lai CL, Liu CK, Lan SH, Hsu CY. Isolated sleep paralysis linked to impaired nocturnal sleep quality and health-related quality of life in Chinese-Taiwanese patients with obstructive sleep apnea. Qual Life Res. 2010;19(9):1265-72

31. Amann VC, Maru NK, Jain V.Hypersomnolence in Wilson disease." J Clin Sleep Med. 2015 15;11(11):1341-3.

32. Nevsimalova S, Buskova J, Bruha R, Kemlink D, Sonka K, Vitek L, et al. Sleep disorders in Wilson's disease. Eur J Neurol. 2011;18(1):18490.
33. Anderson KN, Pilsworth S, Sharples LD, Smith IE, Shneerson JM. Idiopathic hypersomnia: a study of 77 cases. Sleep. 2007;30(10):1274-81.

34. Karacan I, Thornby JI, Anch M, Booth GH, Williams RL, Salis PJ. Dose-related sleep disturbances induced by coffee and caffeine. Clin Pharmacol Ther. 1976;20(6):682-9

35. Phillips BA,Danner FJ Cigarette smoking and sleep disturbance." Arch Intern Med. 1995 Jul;155: 740-737.

36. https://icd.who.int [strona domowa w Internecine] [cytowana 22 lipca 2018].

37. https://dsm.psychiatryonline.org [strona domowa w Internecine] [cytowana 22 lipca 2018].

38. Sharpless BA, McCarthy KS, Chambless DL, Milrod BL, Khalsa SR, Barber JP. Isolated sleep paralysis and fearful isolated sleep paralysis in outpatients with panic attacks. J Clin Psychol. 2010;66(12):1292-306.

39. Paradis C, Friedman S, Hinton DE, McNally RJ, Solomon LZ, Lyons KA.The assessment of the phenomenology of sleep paralysis: the Unusual Sleep Experiences Questionnaire (USEQ). CNS Neurosci Ther. 2009;15(3):220-6

40. Fulda S, Hornyak M, Müller K, Cerny L, Beitinger PA, Wetter TC. Development and validation of the Munich Parasomnia Screening (MUPS). Somnologie - Schlafforschung und Schlafmedizin. 2008;12:56-65.

41. Cheyne JA. Situational factors affecting sleep paralysis and associated hallucinations: position and timing effects.J Sleep Res. 2002;11(2):169-77.

42. Stores G. Medication for sleep - wake disorders. Arch Dis Child. 2003;88: 899-903.

43. Hishikawa Y, Ida H, Nakai K, Kaneko Z. Treatment of narcolepsy with imipramine (tofranil) and desmethylimipramine (pertofran). J Neurol Sci. 1966;3(5):453-61.

44. Koran LM, Raghavan S.Fluoxetine for isolated sleep paralysis. Psychosomatics. 1993;34(2):184-7.

45. Schrader H, Kayed K, Bendixen Markset AC, Treidene HE. The treatment of accessory symptoms in narcolepsy: a double-blind cross-over study of a selective serotonin re-uptake inhibitor (femoxetine) versus placebo. Acta Neurol Scand. 1986;74(4):297303.

46. Jalal B.How to make the ghosts in my bedroom disappear? Focusedattention meditation combined with muscle relaxation (MR therapy) - a direct treatment intervention for sleep paralysis. Front Psychol. 201629;7:28.

\section{Correspondence address:}

Paulina Wróbel - Knybel

I Klinika Psychiatrii, Psychoterapii

i Wczesnej Interwencji

20-439 Lublin, ul. Głuska 1

E-mail: polinkawrobel@interia.pl

Otrzymano: 03.08.2018

Zrecenzowano:01.10.2018

Przyjęto do druku: 25.10.2018 